\title{
A Review of the Development and Applicability of Double-Skin Facades in Hot Climates
}

\author{
Aare N. Abtar \\ Department of Architecture, College of Engineering, University of Sulaimani, Sulaimani, Kurdistan Region - F.R. Iraq
}

\begin{abstract}
A double-skin façade (DSF) is a multilayered skin that was initially designed for the cold climate of European countries with noticeable success. Since then, countries in different climates started looking into the possibility of adopting DSF through the use of computer simulations to avoid any unforeseen problems in real life. This study aims to look into the possibility and level of success in using DSF in the Middle East's hot-arid climate, making it a challenge compared to European countries. The study utilized a quantitative investigative approach in analyzing the results of some studies done in different countries in the Middle East. After looking into the results from different papers, careful considerations have to be made for the building due to its location and microclimate to determine specific parameters (e.g., combination of transparent and opaque materials, proportion between floor level and screen height, orientation and cavity depth), these would lead to a significant impact on reducing a building's cooling loads and energy efficiency. It is worth noting that mechanical ventilation (e.g., supplying all return cool air from internal spaces into the DSF cavity or integrating the building's heating, ventilation, and air-conditioning system with the façade) is necessary for DSF in hot climates to cool and maintain its cavity's temperature to function properly. However, this increases cooling loads, energy consumption, and running costs of the building which architects have to consider to determine the most efficient and economical solution in material and equipment.
\end{abstract}

Index Terms-Arid regions; Double-skin Façade; Hot climate; Middle East

\section{INTRODUCTION}

Double-skin façade (DSF) is a technology designed in Europe (for cold climates) to save energy on heating and enhance indoor comfort in a building that is identified as a multilayered structure composes of an outer skin, a cavity, and an inner skin (Streicher, et al., 2005; Zhou and Chen, 2011), illustrated in Fig. 1.

The DSF system has taken its present form over a number of years of its application, predominantly seen in the European countries; it is now picking up in the USA and other countries, and has become synonym with the

ARO-The Scientific Journal of Koya University

Vol. IX, No.2 (2021), Article ID: ARO.10859, 11 pages

DOI: $10.14500 /$ aro. 10859

Received: 22 August 2021; Accepted: 22 November 2021

Regular research paper: Published: 20 December 2021

Corresponding author's e-mail: ari.abtar@univsul.edu.iq Copyright (C) 2021 Aari N. Abtar. This is an open-access article distributed under the Creative Commons Attribution License. applications of transparent and glass architecture. It is also becoming an efficient environmental design strategy for energy savings and life cycle costs (Boake, 2001).

In this age, DSF is becoming a common architectural feature of commercial buildings. "The challenge for DSF buildings is to maintain a balance between the esthetic, acoustics insulation, and visual benefits against the performance of the building from energy point of view" (Yagoub, Appleton and Stevens, 2010).

After its successful application in the European region, many other countries of different climates are starting to consider studies and researches about DSF to try adapting it into different weathers to be able to maintain a good comfort zone and reduce energy consumption as much as possible.

\section{CLASSIFICATION OF DSF}

DSF can be identified into the following types: (Knaack, et al., 2007).

\section{A. Box Window}

Each box is enclosed horizontally and vertically and has its own air circulation, Fig. 2.

\section{B. Shaft Box}

This type extracts air from its own cavity into special adjacent shafts that extend over several stories for stack effect, Fig. 2.

\section{Corridor}

Partitioned at each floor level or may extend over several floors. Air vents on external skin should be located near the floor and ceiling for each level. Natural, mechanical, and hybrid are three possible ventilation types, Fig. 2.

\section{Multistorey}

Cavity space between inner and outer skins extends over the entire façade or in some cases by a number of rooms and floors without any dividers. Vent openings are located near the ground and the roof, Fig. 2.

\section{Advantages of DSF}

According to a study by Ghasemi and Ghasemi, 2017, double-skin facades have a wide range of properties and 
advantages that can be fully utilized to improve the overall performance and esthetics of our buildings, some of these advantages are the following:

- Reduction of heating energy

- Sunlight radiation control

- Possibility of natural air conditioning.

\section{Considerations in Hot Climate Regions}

It has been claimed that DSF should have low thermal transmission (U-value) and low solar heat gain coefficient (G-value) to function properly (Kragh, 2000), as shown in Fig. 3. Therefore, it is necessary to design a system that decreases solar gain and air temperature inside the

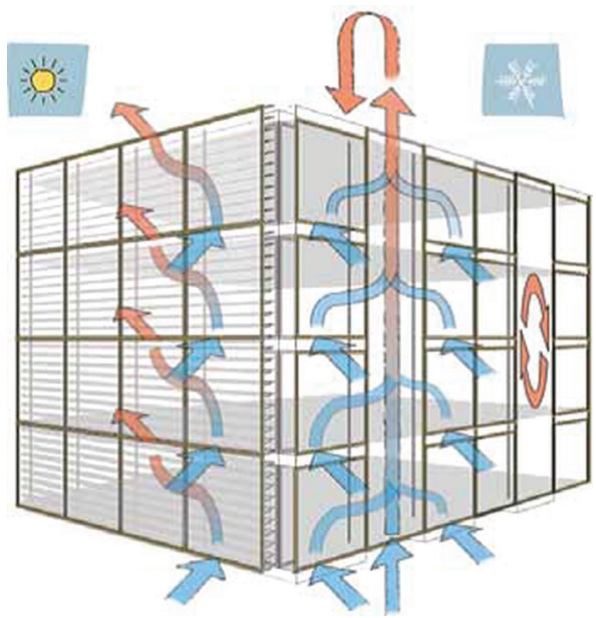

Fig. 1. Components and work mechanism of a double-skin façade (Poirazis 2004).

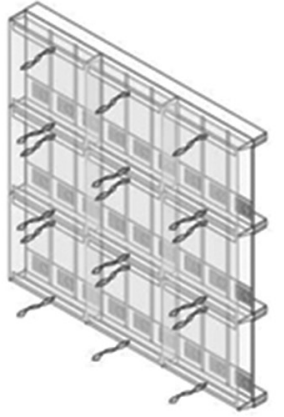

Box-window

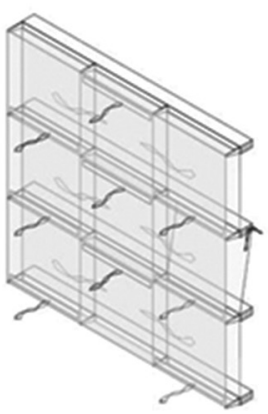

Corridor

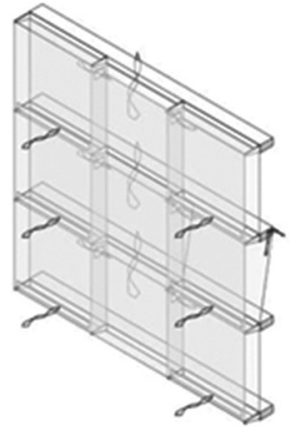

Shaft-box

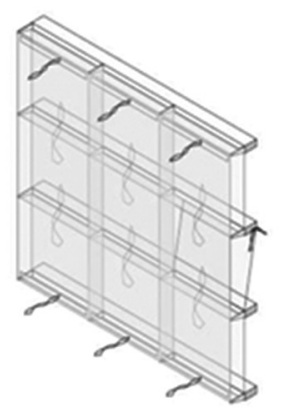

Multi-storey
Fig. 2. Illustrations of the four types of DSF (Knaack 2007). cavity during the summer season, this would decrease the internal surface temperature which leads to a reduction in cooling loads. A proper combination of the type of DSF and geometry, size of openings, type, and positioning of shading devices can improve building performance.

In addition, DSF has the potential of providing acceptable internal thermal comfort levels through natural ventilation. Considering the climate, the building's orientation can be decided based on the prevailing wind, which can make natural ventilation possible in summer (Azarbayjani, 2011).

However, application of DSF in hot climates will not be as easy as it is in cold and temperate climates, as several things must be considered to implement solutions and improvements into the envelope, such as:

- High external temperature in summer; this will greatly affect the external layer and the cavity.

- Sand storms in the region; affecting designs and mechanism for the cavity.

- Maintenance and cleaning of the cavity due to dust and sand.

- Complexity of the building shape; due to the above factors, how much can be done in terms of its shape.

\section{Methodology}

This study will utilize a quantitative investigative approach, by looking into the previous studies on DSF in similar climates to Iraq using the Köppen-Geiger classification system, as shown in Fig. 4, that divides Iraq into the three following regions; (Csa) [warm temperate, summer dry, and hot summer] in the north, (Bsh) [arid, summer dry, and hot arid] in the middle, and (BWh) [arid, desert, and hot arid] in the southern regions. Besides, discussing and comparing their findings through computer simulations are undertaken to better understand their local climate, regulations, software and technological capabilities, and approach to utilizing DSF.

\section{Review: Case Studies and Application Analysis}

Multiple studies and analyses have been made to find out how much DSF is effective in temperate, hot, and arid

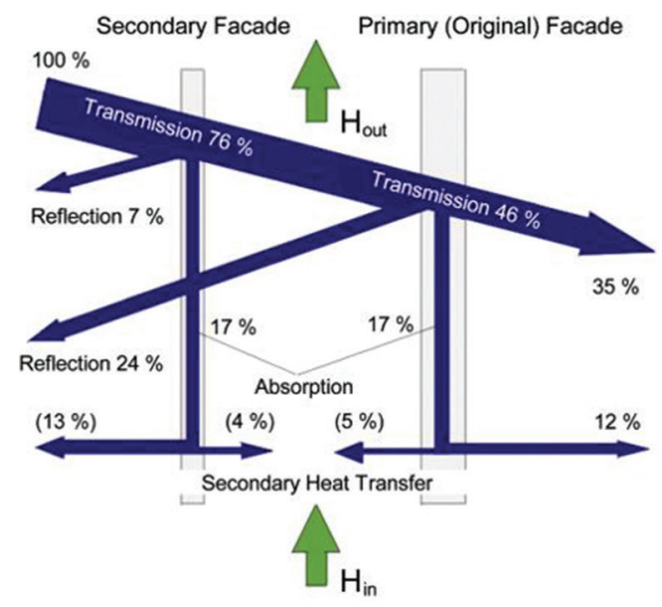

Fig. 3. Heat transfer phenomena in a double-skin façade (Blumenberg, et al., 2006). 
climates (especially within the Middle East) and looking for different possibilities to modify and adapt its current form (for Europe and cold regions) for the hot regions.

\section{A. Case Study: Cairo World Trade Center in Cairo, Egypt}

In a research (Hamza, 2008), the author mentions that understanding the performance of DSF configurations in extreme hot-arid climates is little. Therefore, her investigation adopted an analytical approach using a dynamic simulation software (IESVE). Afterward, the author attempted a comparative analysis of cooling loads on a single skin base case which is based on the third tower of the Cairo World Trade Center (to the left in Fig. 5) by Skidmore, Owings, and Merrill (SOM), compared against three possible changes to the physical properties of the external layer of the DSF.

Fig. 6 shows that the physical attributes of the base case model are a square plan and not surrounded by other buildings. Besides, the parameters listed in Table I are used for the default walls and the DSF layers. The majority of office buildings in Cairo were built the same way, this is shown in Fig. 6, which appears to have been used in constructing other base case morphologies in different climates to easily calculate the influence of changing façade configurations on its cooling loads (Lam, 2000).

The simulation's results in Fig. 7 predict an increase in annual cooling loads due to the low direct solar radiation reflection properties of clear glazing, showing that a transparent DSF has poor thermal performance compared to a well-designed single skin. The results also predict that cooling loads on the East, West, and South orientations will be $12 \%$ lower than a benchmark single skin. Hamza suggested that the heat trapped in the channel would encourage natural buoyancy which, in turn, would reduce heat gain (Hamza and Underwood, 2005).

Moreover, the results indicate that using a reflective DSF can achieve better energy savings compared to a single skin with reflective glazing, as the selective reflective glass on the outer layer of the DSF shows the highest possible decrease in cooling loads (approximately 30\%). Furthermore, using glazing with lower shading coefficient and g-value (total solar energy transmittance) should be considered rather than transparent glass on the external layer to provide the first line of defense against the direct solar radiation in hot-arid climates.

\section{B. Case Study: National Holding Headquarters in Abu Dhabi, UAE}

A simulation analysis research was done by Yagoub, Appleton and Stevens, 2010, on the National Holding Headquarters' building shown in Fig. 8, which is designed by Zaha Hadid Architects and located in Abu Dhabi (which has a hot and arid climate similar to the southern regions of Iraq) to determine its effectiveness. In this paper, the data in Tables II and III were considered as the properties of the DSF glazing and the thermal parameters.

Initial results in Fig. 9 show that due to high outdoor temperatures, the DSF's gap had very high temperatures,

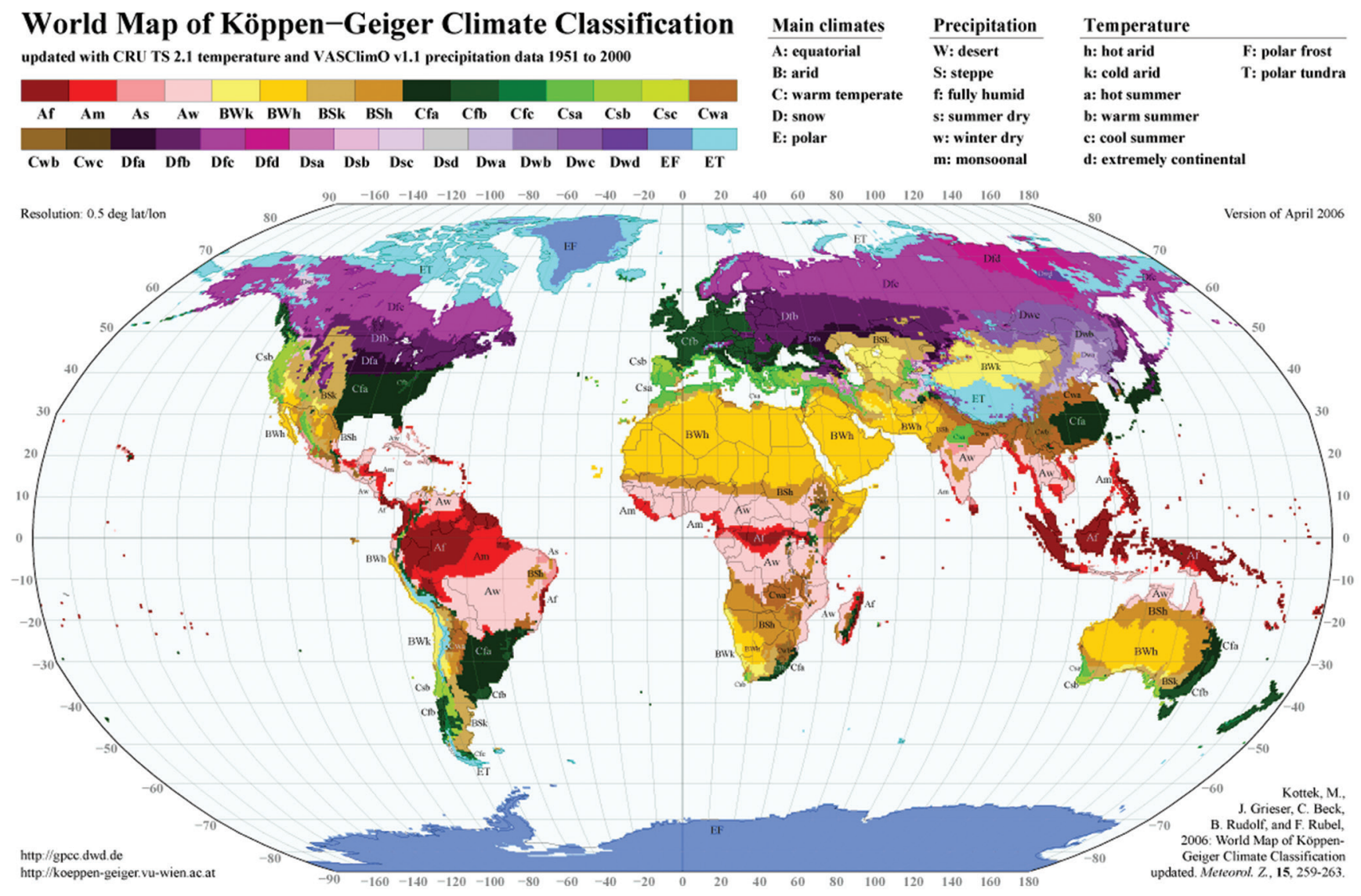

Fig. 4. Köppen-Geiger Climate Classification Map (Rubel and Kottek, 2010). 
TABLE I

Glazing and Thermal Properties for the Outer Leaf of the Double-Skin FaÇade (Hamza, 2008)

\begin{tabular}{|c|c|c|c|c|c|c|c|}
\hline Glazing thickness & \multicolumn{2}{|c|}{ Window-to-wall ratio } & "Wall & \multicolumn{4}{|l|}{ "U-value (Wall) } \\
\hline $6 \mathrm{~mm}$ panel & \multicolumn{2}{|l|}{$40 \%$} & $\begin{array}{l}\text { Single brick, } \\
\text { uninsulated, } \\
\text { plastered on } \\
\text { both sides }\end{array}$ & \multicolumn{4}{|l|}{$1.4 \mathrm{~W} / \mathrm{m}^{2} \mathrm{~K}$} \\
\hline Exterior leaf glazing type & U-value $\left(\mathrm{W} / \mathrm{m}^{2} \mathrm{~K}\right)$ & Solar coefficient (SC) & g-Value & Thickness (mm) & Transmittance (\%) & Reflection (\%) & Absorption (\%) \\
\hline Clear glazing & 5.6 & 0.85 & 0.87 & 10 & 73 & 7 & 20 \\
\hline Body tinted green & 5.6 & 0.59 & 0.51 & 10 & 35 & 5 & 60 \\
\hline \multicolumn{8}{|c|}{ Glazing properties for internal glazing $40 \% \mathrm{WWR}$ of the double-skin façade } \\
\hline Clear glazing & 5.6 & 0.95 & 0.82 & 6 & 79 & 7 & 14 \\
\hline Single glazing type & U-value $\left(\mathrm{W} / \mathrm{m}^{2} \mathrm{~K}\right)$ & Solar coefficient (s & g-Value & Thickness (mm) & Transmittance $(\%)$ & Reflection $(\%)$ & Absorption (\%) \\
\hline \multicolumn{8}{|c|}{ Glazing properties simulated for the sing skin base case façade (BC) } \\
\hline Clear glazing & 5.6 & 0.95 & 0.82 & 6 & 79 & 7 & 14 \\
\hline
\end{tabular}

TABLE II

Properties of the Glazing (Yagoub, et AL., 2010)

\begin{tabular}{|c|c|c|c|}
\hline Exterior leaf glazing type & External skin & Internal skin external glass & Internal skin internal glass \\
\hline Thickness (mm) & 10 & 8 & 8.76 \\
\hline Conductivity (W/m K) & 1 & 1 & 1 \\
\hline \multirow[t]{2}{*}{ Type of glass } & Pyrolytic coating with gold appearance on outer & \multirow[t]{2}{*}{ Clear glass with low-E coating } & Clear laminated glass \\
\hline & Surface & & Uncoated \\
\hline Light transmittance & $38 \%$ & $87 \%$ & $87 \%$ \\
\hline Light reflectance (outside) & $35 \%$ & $5 \%$ & $8 \%$ \\
\hline Solar reflectance (outside) & $21 \%$ & $20 \%$ & $6 \%$ \\
\hline Solar reflectance (inside) & $30 \%$ & $30 \%$ & $6 \%$ \\
\hline Outside emissivity & 0.84 & 0.84 & 0.84 \\
\hline Inside emissivity & 0.84 & 0.04 & 0.84 \\
\hline U-value (W/m² K) & 5.56 & 3.2 & 5.6 \\
\hline
\end{tabular}

TABLE III

InPut Parameters for the Thermal Model (Yagoub, et AL., 2010)

\begin{tabular}{ll}
\hline \hline Element & Value \\
\hline Humidity in the offices space & Minimum $40 \%$ and maximum $60 \%$ \\
Temperature of the internal office space & $24^{\circ} \mathrm{C}$ (constant) \\
$\begin{array}{l}\text { Miscellaneous internal gains } \\
\text { (e.g., small power) }\end{array}$ & $15 \mathrm{~W} / \mathrm{m}^{2}$ \\
Lighting internal gains & $18.75 \mathrm{~W} / \mathrm{m}^{2}$ \\
Occupancy density & $9 \mathrm{~m}^{2}$ per person \\
Infiltration & 0.25 air change per h \\
Simulation period & Whole year round \\
\hline \hline
\end{tabular}

this would affect greatly what the indoor surface temperature was required to be at. Thus, solutions were sought to reduce the temperature of the DSF skins and try to maintain it at a below level. It was suggested that the DSF gap's temperature to be either maintained at $45^{\circ} \mathrm{C}$ or $60^{\circ} \mathrm{C}$, as $45^{\circ} \mathrm{C}$ was the assumed external temperature for the design and $60^{\circ} \mathrm{C}$ was the maximum operating temperature for the shading blind motors.

Considering energy efficiency, it is beneficial to maintain the DSF cavity's temperature at the same external air

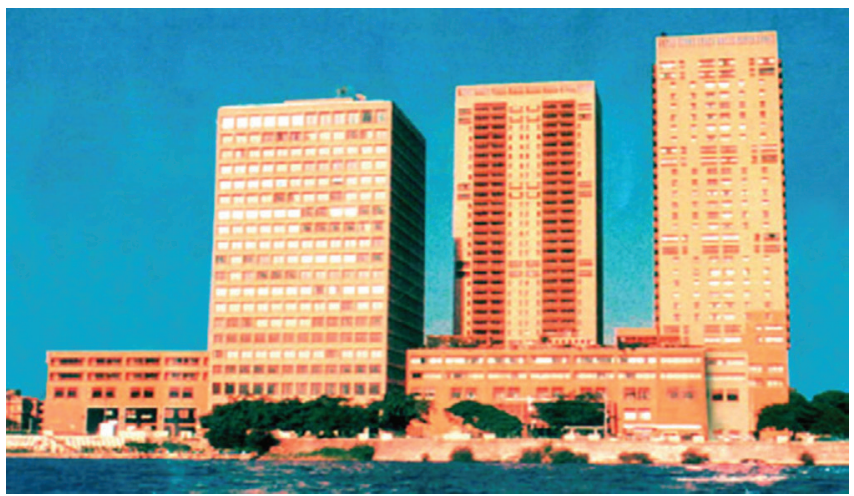

Fig. 5. Cairo World Trade Center designed by SOM (Hamza, 2008).

temperature $\left(\sim 45^{\circ} \mathrm{C}\right)$; however, this requires all the internal spaces' return cool air to be supplied to the cavity in addition to the extra cooling load. For example, the author stated that each floor had an estimated ventilation flow rate of $1500 \mathrm{l} / \mathrm{s}$ and cooling load of $192.6 \mathrm{~kW}$. However, to be able to lower and maintain at $45^{\circ} \mathrm{C}$, additional air $(3000 \mathrm{l} / \mathrm{s})$ will be needed leading to an additional cooling load of $44 \mathrm{~kW}$. Whereas maintaining the cavity at $60^{\circ} \mathrm{C}$ needs an estimated $800 \mathrm{l} / \mathrm{s}$ 


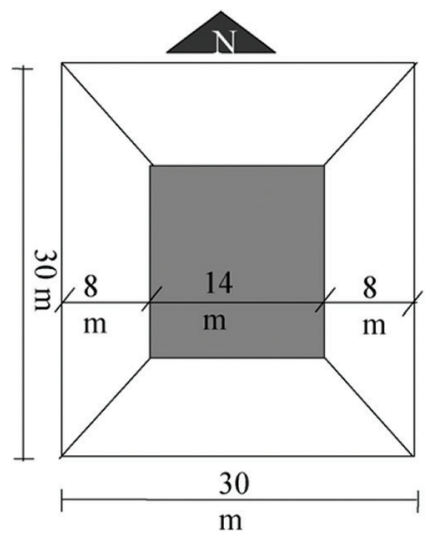

Typical Floor Plan

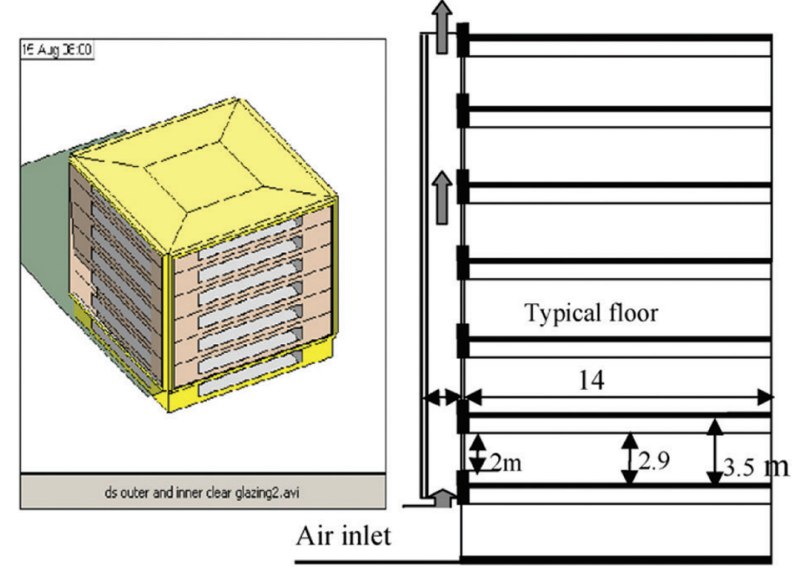

Fig. 6. Physical attributes of the base case model, showing the location of the air inlet (Hamza, 2008).

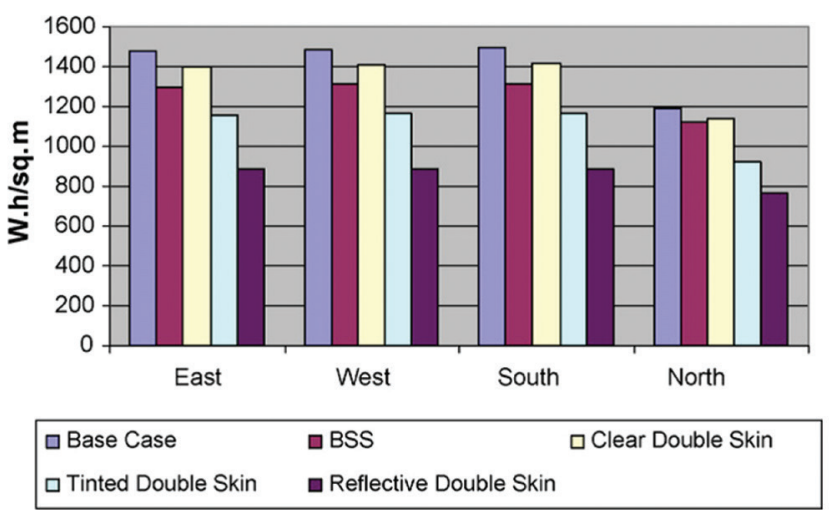

Fig. 7. Comparison between single skin and double skin on annual total cooling loads (Hamza, 2008).
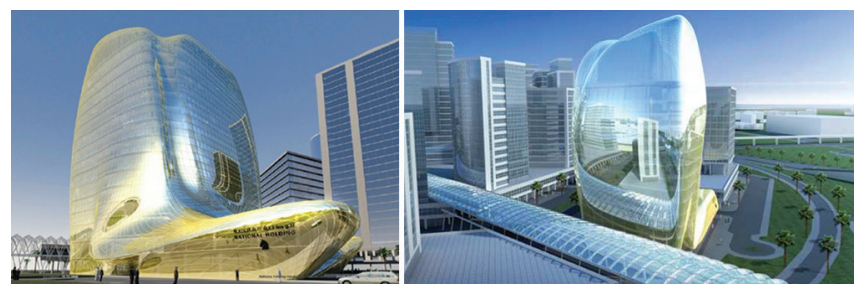

Fig. 8. External views of National Holding's building (right: Yagoub, Appleton and Stevens, 2010) (left: Wallner and Pottman, 2011).

which is $20.6 \mathrm{~kW}$ worth of additional cooling load, this allows partial heat recovery which lets the motorized blinds to operate with minimum risk, as shown in Fig. 10.

Based on the results, it is possible to achieve comfortable internal conditions using DSF. However, it is unavoidable to allow for an element of energy consumption dedicated to maintain the cavity's temperature. This impacts the overall building energy consumption leading to higher running costs in the long run.

\section{Case Study: Office Buildings in Riyadh}

In another research (Alahmed, 2013), the author referenced the previous study's findings and tried to move it further to get improved and better solutions by conducting simulations

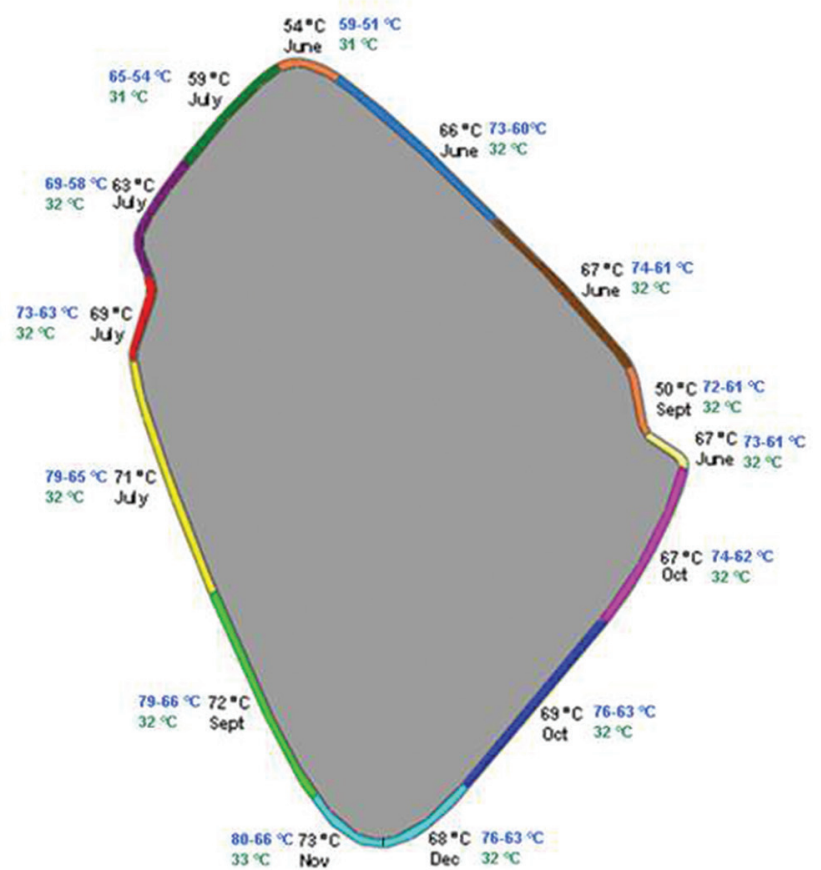

Sectors peak temperature $\left({ }^{\circ} \mathrm{C}\right)$

DSF gap: outer skin - inner skin (facing the gap) surface temperature $\left({ }^{\circ} \mathrm{C}\right.$ ) Glazing surface temperature (facing the internal office space) $\left({ }^{\circ} \mathrm{C}\right.$ )

Fig. 9. Air and glazing surface temp. variation along the double-skin gap (Yagoub, Appleton and Stevens, 2010).

on a hypothetical building model seen in Fig. 11, which is based on multiple existing office buildings in Riyadh, Saudi Arabia, which uses the country's specific building regulations and specifications listed in Table IV.

Buildings that were considered as case studies were not energy efficient at all, and their facades were proposed to be changed into DSF to improve their performance, as shown from Fig. 12. Moreover, for the simulation, the given information in Table $\mathrm{V}$ was used.

Preliminary simulations and analyses were made to find out the most important variables, for example, determining the most effective cavity depth of the DSF on the energy consumption as shown in Fig. 13. The author also looked 
TABLE IV

Saudi Regulations for Glazing Areas in Buildings (Alahmed, 2013)

Window and Glazed Door Area Greater than 40\% but not Greater than 50\% of Above-Grade Wall Area

\begin{tabular}{|c|c|c|c|}
\hline Element & Condition/Value & & \\
\hline Skylights (U-factor) & 4.542 & & \\
\hline Slab or below-grade wall (R-value) & R-1.409 & & \\
\hline Windows and glass doors & "Solar heat gain factor (SHGC) & U-factor & \\
\hline $\mathrm{PF}<0.25$ & 0.4 & 2.271 & \\
\hline $0.25 \leq \mathrm{PF}<0.50$ & 0.5 & 2.271 & \\
\hline $\mathrm{PF} \geq 0.50$ & 0.6 & 2.271 & \\
\hline Metal joist/truss & R-5.284 & R-4.227 & \\
\hline Concrete slab or deck & NA & R-4.051 & \\
\hline Metal purlin with thermal block & R-6.692 & $\mathrm{R}-4.227$ & \\
\hline Metal purlin without thermal block & R-6.692 & $\mathrm{R}-4.227$ & \\
\hline Floors over outdoor air or unconditioned space (R-value) & Insulation between framing & Continuous insulation & \\
\hline Framed: R-value cavity & NA & R-2.289 & R-1.937 \\
\hline R-value continuous & NA & $\mathrm{R}-3$ & $\mathrm{R}-0$ \\
\hline \multicolumn{4}{|l|}{ Concrete masonry units $(\mathrm{CMU})>200 \mathrm{~mm}$ : } \\
\hline R-value cavity & NA & R-1.937 & R-1.937 \\
\hline R-value continuous & R-0.881 & $\mathrm{R}-0$ & $\mathrm{R}-0$ \\
\hline \multicolumn{4}{|l|}{ Other masonry walls: } \\
\hline R-value cavity & NA & R-1.937 & R-1.937 \\
\hline $\mathrm{R}$-value continuous & R-0.881 & R-0 & $\mathrm{R}-0$ \\
\hline
\end{tabular}

$\mathrm{DD}(\mathrm{F})=\mathrm{DD}(\mathrm{C})^{*} 1.8 ; 1 \mathrm{~W} / \mathrm{m}^{2} \mathrm{~K}=0.1761 \mathrm{BTU} /\left(\mathrm{hr} . \mathrm{ft} 2^{\circ} \mathrm{F}\right) ; 1 \mathrm{~m}^{2} \mathrm{~K} / \mathrm{W}=5.678{\mathrm{~h} . \mathrm{ft}^{2}}^{\circ} \mathrm{F} / \mathrm{BTU}$

TABLE V

InPut Details for the GlaZing and Construction Materials (Alahmed, 2013)

\begin{tabular}{|c|c|c|c|}
\hline Elements & Materials & Thickness & U-value $\left(\mathrm{W} / \mathrm{m}^{2} \mathrm{~K}\right)$ \\
\hline Walls & Insulated concrete & $45.5 \mathrm{~cm}$ & 0.25 \\
\hline Roof & Insulated reinforced concrete & $42.5 \mathrm{~cm}$ & 0.23 \\
\hline Floors & Reinforced concrete ceilings & $30 \mathrm{~cm}$ & 2.4 \\
\hline Internal Walls & Concrete blocks & $13 \mathrm{~cm}$ & 1.16 \\
\hline Location & Description & U-value $\left(\mathrm{W} / \mathrm{m}^{2} \mathrm{~K}\right)$ & Total R-value $\left(\mathrm{m}^{2} \mathrm{~K} / \mathrm{W}\right)$ \\
\hline Single skin facades & Double-glazed windows reflective coating & 2.92 & 0.17 \\
\hline $\begin{array}{l}\text { Double skin facades } \\
\text { (external skin) }\end{array}$ & Single-glazed windows reflective coating & 5.41 & 0.0057 \\
\hline $\begin{array}{l}\text { Double-skin facades } \\
\text { (internal skin) }\end{array}$ & Double-glazed low-E windows & 1.67 & 0.33 \\
\hline
\end{tabular}

into the possibility of replacing heating, ventilation, and airconditioning (HVAC) systems with DSF, but this would not be ideal in hot climates due to the cavity's hot air. Thus, the cavity may be utilized as a part of the HVAC system instead of replacing it entirely. The end variables that were selected for the study were the following in Table VI.

After extensive simulations and analysis, the study showed that most DSF scenarios had significant energy use reduction compared to baseline cases of the same building. The most effective type of DSF was found to be the box window type with effective configurations when the cavity was located on the western and eastern facades and used wider cavity depth with mechanical ventilation, as it provided extra protection compared to single skin facades and reduced solar gains in rooms next to the cavity. Consequently, cooling loads
TABLE VI

SiMULATION VARIABLES SELECTED FOR STUDY (AlAHMED, 2013)

\begin{tabular}{llll}
\hline \hline Installation type & Orientations & Cavity depth & Ventilation in cavity \\
\hline Multistorey & South & $100 \mathrm{~cm}$ & Natural \\
Corridor & North & $150 \mathrm{~cm}$ & Mechanical \\
Box window & East & & \\
& West & & \\
\hline \hline
\end{tabular}

were decreased. In addition, inner surface temperatures were dropped due to the injected exhaust air from the HVAC system, as shown in Fig. 14. In turn, it reduced energy consumption by $8.05 \%$ and $4.78 \%$, respectively, in comparison to the baseline without and with shading.

The study's results give us a better picture regarding orientation and mechanical options when DSF is considered 

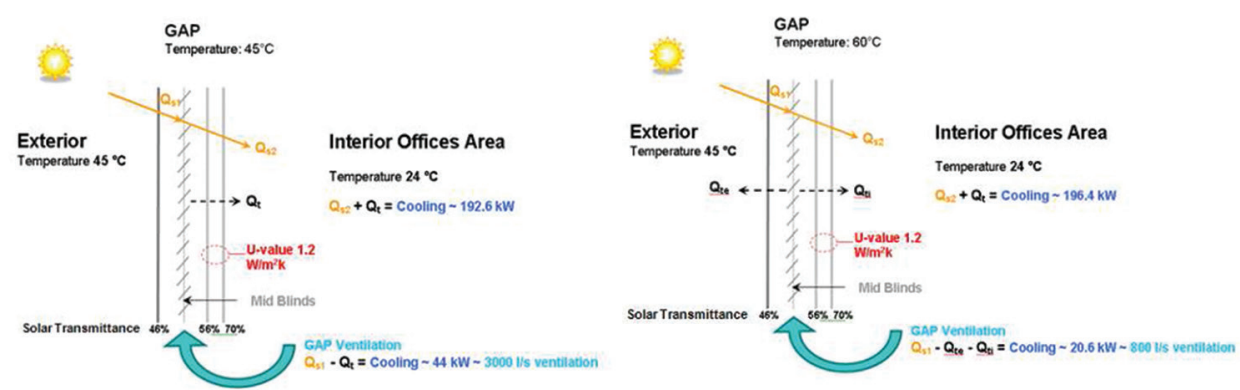

Fig. 10. Section of DSF shows cooling requirements for the gap at $45^{\circ} \mathrm{C}$ and $60^{\circ} \mathrm{C}$ (Yagoub, Appleton and Stevens, 2010).
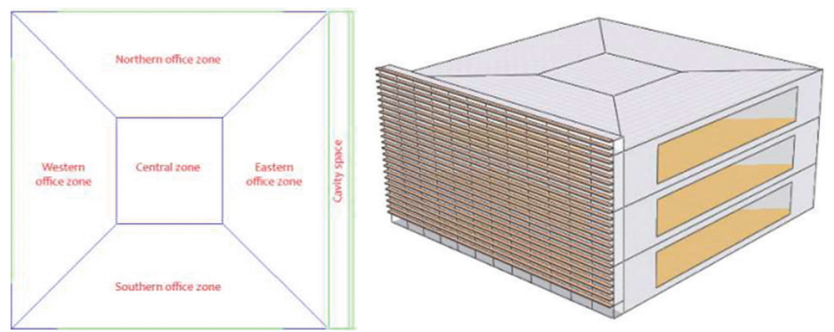

Fig. 11. Simulation building layout and model (Alahmed, 2013).
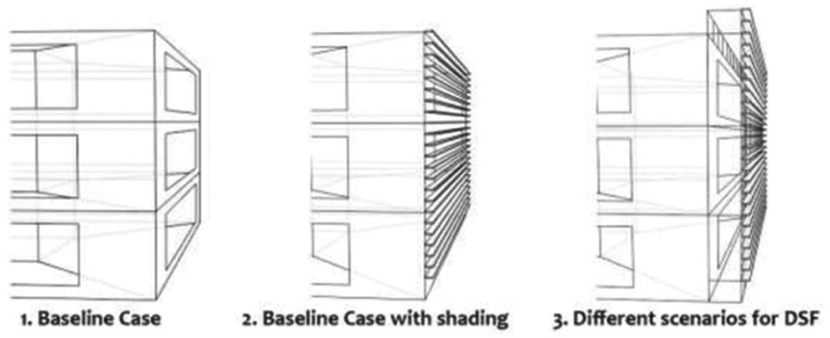

Fig. 12. Illustrations of the different cases for the simulation (Alahmed, 2013).

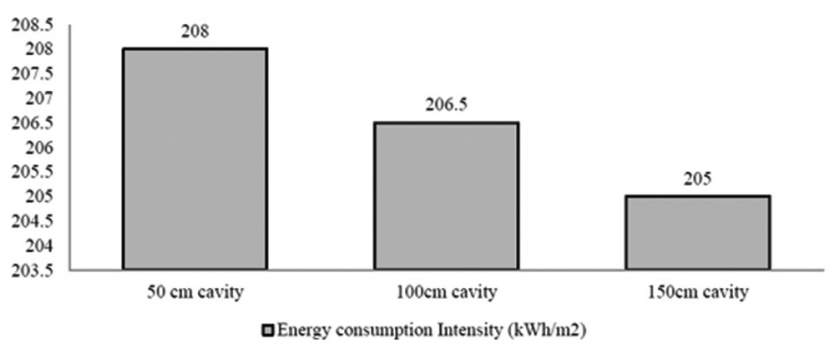

Fig. 13. Energy use intensity $\left(\mathrm{kWh} / \mathrm{m}^{2}\right)$ for different cavity depths for cavity facing east (Alahmed, 2013).

for retrofitting and rehabilitation purposes. However, this approach needs further readings from different locations to get suitable solutions for local buildings.

\section{Case Study: Arch. Engineering Department in}

\section{Al-Ain City, UAE}

In another study (Radhi, Sharples and Fikiry, 2013) in which instead of running computer simulation on base case models, the author simulated an educational building with a multi-façade system within the UAE University campus

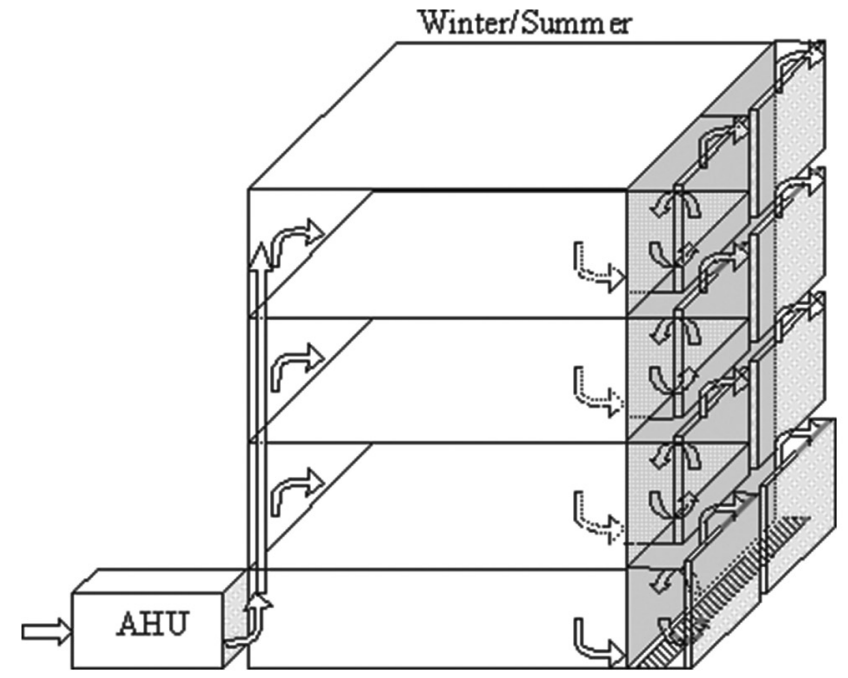

Fig. 14. DSF as an exhaust duct for the heating, ventilation, and airconditioning system (Poirazis, 2004).

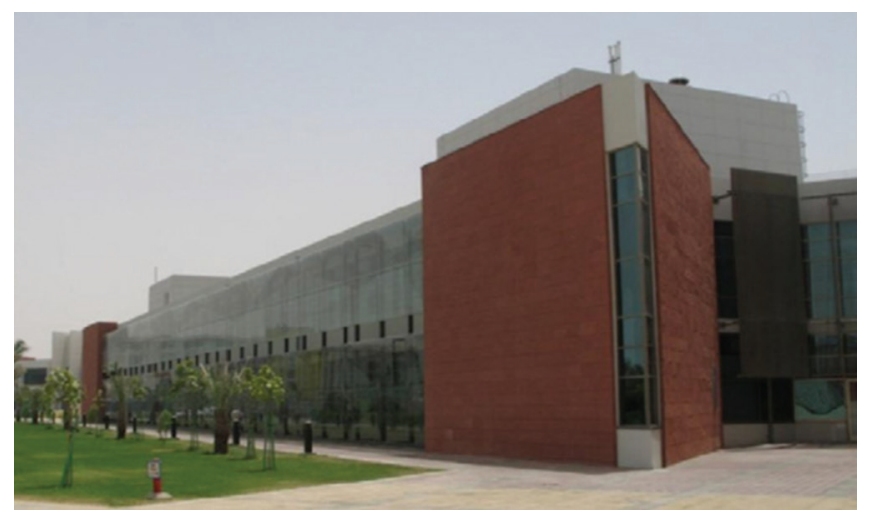

Fig. 15. Arch. Engineering Department in UAE University, Al-Ain City (Radhi, Sharples and Fikiry, 2013).

in Al-Ain City (approximately $100 \mathrm{~km}$ away from Dubai), Figs. 15 and 16 show the exterior of the building and a cross-section of its external skin consecutively.

The author aimed to assess the impact of a climate interactive façade system (CRFS) compared to classical single façade system (CSFS) on cooling energy within fully glazed buildings using building energy simulation and computational fluid dynamics (CFD) as listed in Table VII to establish boundary conditions and also develop geometrical models based on a new constructed multistorey building. 
The initial result presented in Fig. 17 shows that using a CRFS can reduce solar gain within internal spaces, but increases the temperature within the cavity. Regarding cooling loads on a typical summer day in the UAE, the simulation shows that between 17 and $20 \%$ of cooling energy required can be saved. The author states that this range varies from one orientation to another and depends greatly on the level of irradiance and angle of incidence.

From the research's final results, the parameters that have the most impact on cooling loads are floor level related to screen's height, followed by glazing properties and cavity

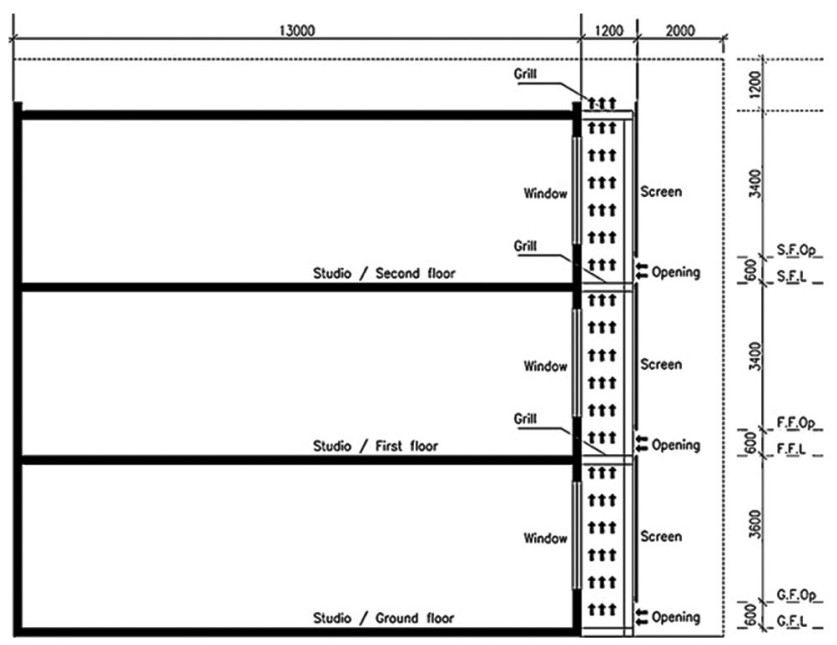

Fig. 16. Cross-section of the studios showing the cavity and air inlet through the DSF (Radhi, Sharples and Fikiry, 2013). depth, respectively. These results offer a reliable indicator of how a climate interactive facade system can have a substantial impact on energy savings, especially for multistorey glazed buildings in hot-arid climates such as in the Middle East.

It is worth noting that in another research (Hashemi, Fayaz and Sarshar, 2010), the author performed field measurements instead of relying on computer simulation for base model predictions for a building with DSF for 2 weeks in summer and 2 weeks in winter in Tehran, Iran (which the country, in general, has a climate more similar to Iraq). That was to observe the behavior of the system in hot and cold conditions. Initial results showed an increase in temperature inside the cavity (reach to $1^{\circ} \mathrm{C}-10^{\circ} \mathrm{C}$ higher compared to outside temperature) due to direct solar radiation. It was also noticed that the cavity temperature could be $12^{\circ} \mathrm{C}$ less than the outside, if the façade was in a shade. The final results showed that this temperature difference between the cavity and the skins can significantly impact heating energy in winter. However, to reduce cooling loads in summer, the author suggested that it was essential to implement additional techniques such as night ventilation and shading devices for the cavity. This aligned with the results from both Yagoub, Appleton and Stevens, 2010, and Alahmed, 2013, works that some form of mechanical ventilation is necessary for DSF in hot-arid climates.

\section{Discussion: TeChNiCAL Specifications}

From the aforementioned researches, it has been found that in every situation of DSF, careful considerations have to be made

TABLE VII

Boundary Conditions of the Base Case Building (East Direction) (Radhi, et al., 2013)

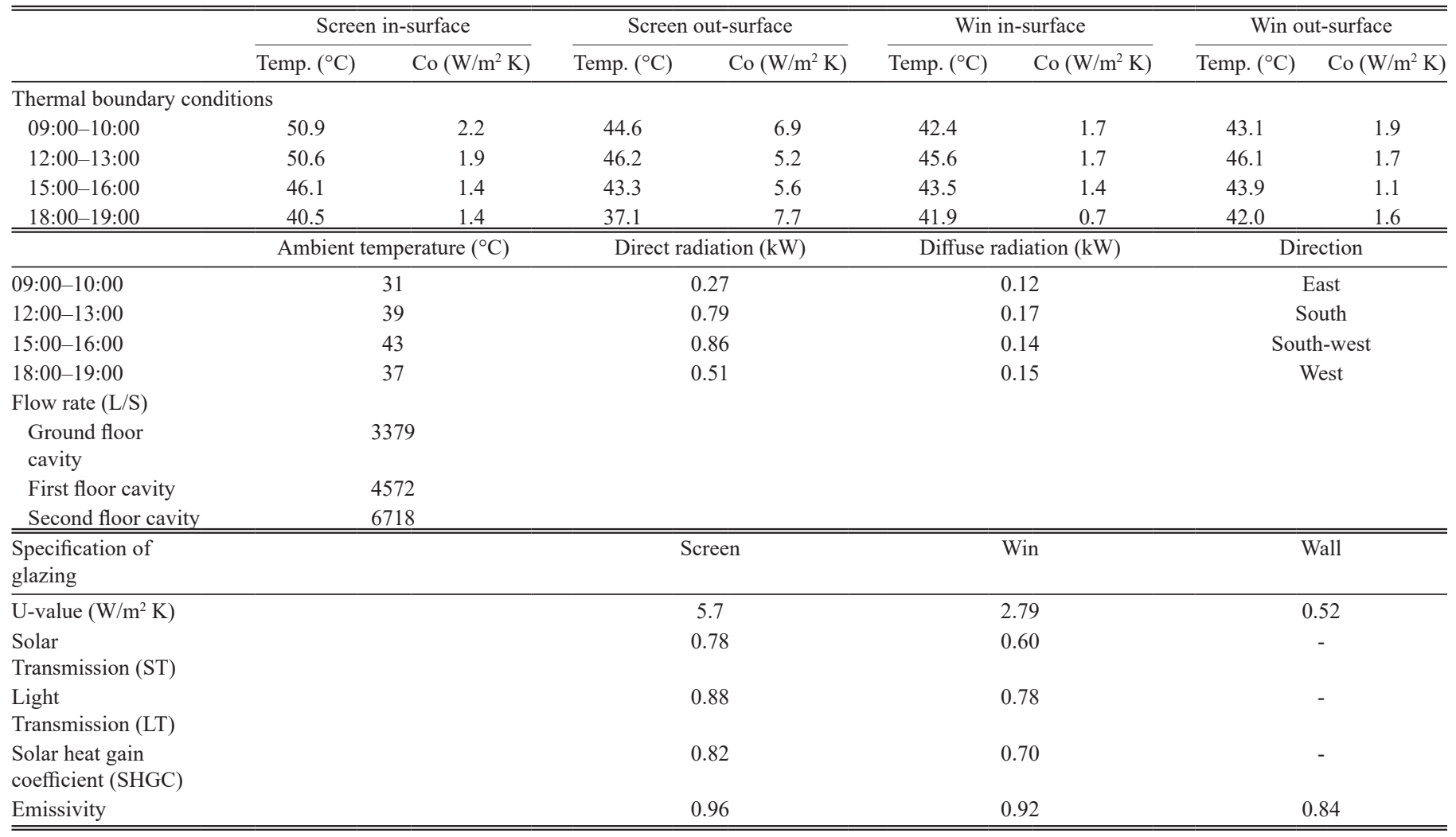



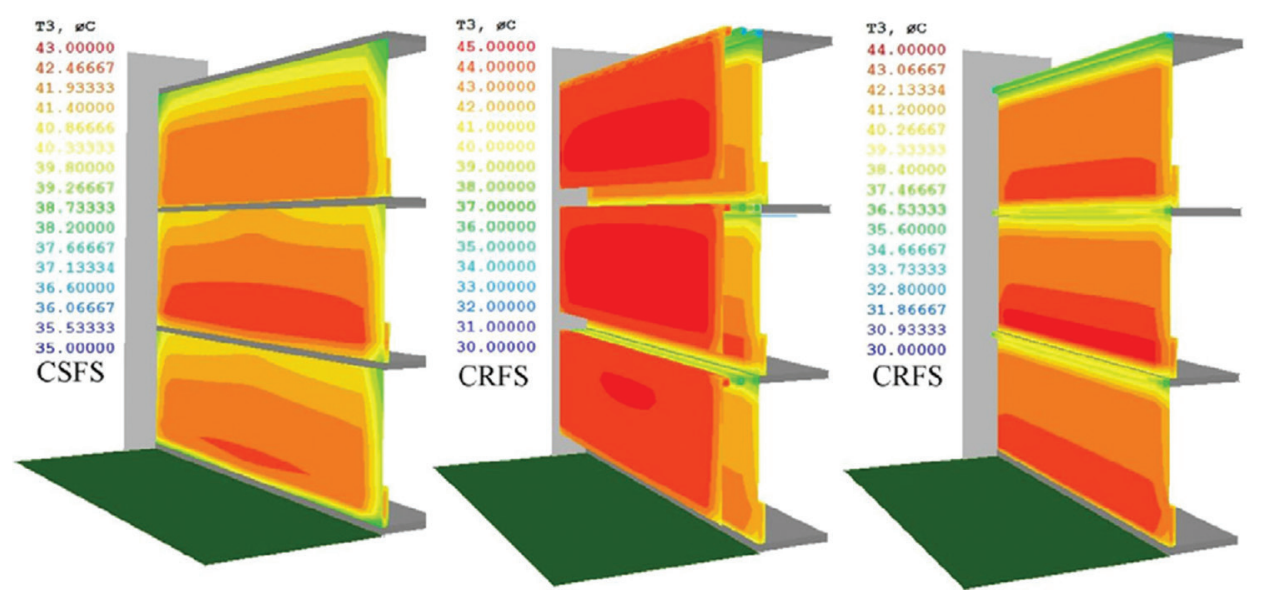

Fig. 17. Comparison of surface temperatures (Radhi, Sharples and Fikiry, 2013).

as each building and its location has its specific requirements and parameters (combination of used materials, using the right proportion and the appropriate orientation) to make DSFs an energy-efficient strategy (Cetiner and Ozkan, 2005). A set of effective guidelines have been proposed for the application of DSF in hot climates, which are the following:

\section{A. Material}

Use materials with a high R-value (thermal resistance) so that there is minimum heat gain, this should not be at the expense of using a vast amount of energy for acquiring them.

\section{B. Glazing Material}

It's necessary to determine how much glass is used, along which façade it is used and if it is appropriately shaded as this can help in reducing the internal temperature of the cavity, therefore, the DSF system wouldn't rely heavily on the mechanical ventilation components, leading to a reduction in the running cost of the system. Additionally, using locally manufactured glass in two layers for the glazed areas may be more cost-effective than using a highly advanced glazing technology that has to be imported.

\section{Nature of Layers}

Layers should not be completely transparent on any of the facades, except the north orientation. The opaque layers may be of the same thickness, or for better insulating effect, the outer layer can be thicker than the inner layer.

\section{Dimensions}

The width of the cavity between the two layers may be decided based on the required need to facilitate ventilation of trapped air and space required for maintenance of the cavity because the U-value of the air space is almost constant after $20 \mathrm{~cm}$ of thickness. Some studies have shown that the cavity can include plants and vegetation to cool the air in the cavity.

\section{E. Nature of the Cavity}

The cavity space between the two layers can be continuous for low-rise structures. It can be partitioned horizontally
U-Value of wall
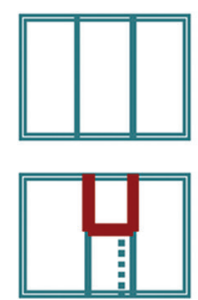

$0.5-1.2 \mathrm{Btu} / \mathrm{h} \mathrm{ft}{ }^{2} \mathrm{~F}$

0.3294

Fig. 18. Comparison of U-values and SHGC (Yellamraju, 2004).

at each floor level for ease of movement of air for taller buildings.

\section{F. U-value}

The overall U-value (thermal transmission) of façade should be reduced for maximum benefit. From simulations, it has been seen that a U-value of $\sim 1.08 \mathrm{~W} / \mathrm{m}^{2} . \mathrm{K} \approx 0.19 \mathrm{Btu} / \mathrm{h}$. $\mathrm{ft}^{2} . \mathrm{F}$ is more efficient than an existing glazed double skin's with a U-value of around $2.8-6.8 \mathrm{~W} / \mathrm{m}^{2} . \mathrm{K}$, which can be reduced depending on the type of glass and shading devices within the cavity, Fig. 18.

\section{G. Solar Heat Gain Coefficient}

The solar heat gain coefficient (SHGC) of a glazed double skin is based on the type of glass used on both the inside and outside, as it is the product of the two layers. Lesser solar heat gain coefficient makes the façade more efficient, Fig. 18.

\section{H. Orientation}

Façades should be designed in such a way that maximum transparency would be on the north orientation and minimum on the south orientation, east and west can have about half the transparency of the north façade. Horizontal shading devices are preferred on the north and south side, and vertical shadings devices on the east and west sides to block off direct sun and glare, Fig. 19.

New shading systems have been devised that are derived from the traditional Islamic Mashrabiya, which is a wooden mesh screen that allows some air circulation while also 


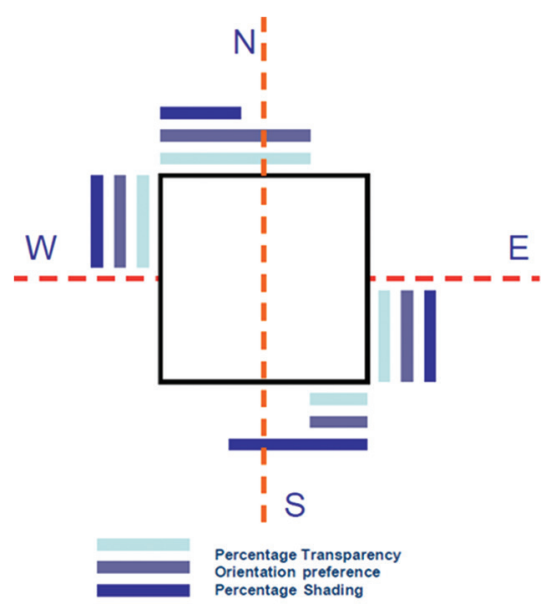

Fig. 19. Design guideline for transparency and shading of the DSF in relation to orientation (Yellamraju, 2004).

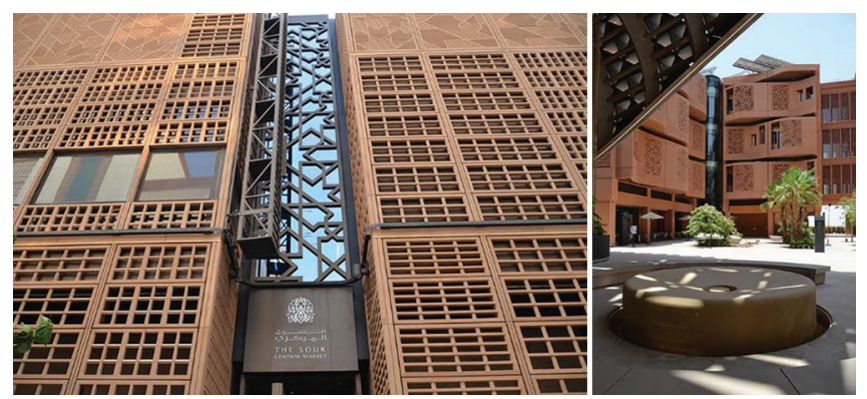

Fig. 20. Modern interpretations of the Islamic Mashrabiya. Left, The Souk and right, Masdar City, located in Abu Dhabi, UAE. By Foster + Partners. (Boake, et al., 2014).

blocking significant solar radiation and providing visual privacy. This vernacular-based feature can be seen to naturally extend as a second layer to create a new type of double façade system. Fig. 20 shows an example of said feature implemented in the buildings of Masdar City in Abu Dhabi.

\section{CONCLUSION}

The first thing to note from the studies is that analytical simulations are of utmost importance before starting to implement the DSF in real life, as to reach the most suitable, reasonable, and economic decision on how to appropriately implement them, thus reducing the chances of having a failed project in hand.

As it is common wisdom in taking advantage of building orientation in the design process to provide suitable indoor thermal comfort, as this will heavily influence the cooling loads and running cost of our buildings. From the hypothetical building case study (Alahmad, 2013), east and west orientations in Riyadh were to be avoided whenever possible as they result in the highest cooling loads. However, for Iraq, orientations should be reexamined alongside the southern orientation to see if their effect is similar to countries such as Saudi Arabia or the UAE. For instance, this will be necessary later on in determining the cavity depth and choosing the most appropriate mechanical ventilation solution for the DSF system.

Regarding the most important component of the DSF, the glazing; results from the studies showed that their optical properties (such as SHGC, U-value, reflectivity, and opacity) are the most effective way to select the most appropriate material for the skins. However, sufficient studies are needed to be done on the local glazing industry in Iraq. This is to see if the available materials are up to the standards in both property and price for an efficient DSF, or we should rely on importing them from other countries.

Moreover, using vernacular elements (as seen in Masdar city's Mashrabiya screens) can be considered good practice in attempting to utilize a region's specific vernacular architecture that is efficient in shading performance. However, duplicating Mashrabiya method without preliminary studies can lead to the emergence of unforeseen problems, especially in Iraqi cities, as the northern regions have a different climate compared to the southern regions. Therefore, further investigations are needed to be done regarding other vernacular architectural features to have options about DSF designs that can be protected and maintained easily during the building's lifetime.

\section{Future StUdiES}

Regarding future studies, it is recommended to start studying aspects of the local context such as the climate, resources, and technologies available in Iraq, to get a better understanding of how ready we are in implementing DSF in our buildings and if there is a need to establish new guidelines and regulations regarding the use of DSF in the buildings. Furthermore, another aspect that can be utilized is building monitoring and model simulations for existing case studies that have significant social or cultural values in Iraq to look into the possibility of rehabilitating the buildings that have poor energy performance and thermal comfort.

\section{REFERENCES}

Alahmed, Z.A., 2013. Double-Skin Façade in Hot-Arid Climates Computer Simulations to Find Optimized Energy and Thermal Performance of Double Skin Facades, MSc Thesis, University of Southern California, Los Angeles.

Azarbayjani, M., 2011. Climatic based consideration of double skin façade system: Natural ventilation performance of a case study with double skin façade in Mediterranean climate. In: $13^{\text {th }}$ Conference of International Building Performance Simulation Association, IBPSA France, Chambéry.

Blumenberg, J., Spinnler, M. and Sattelmayer, T., 2006. Double skin façade systems-a comprehensive review on thermal and energetic behavior. In: International Conference on Recent Advances in Heat Transfer, Technische Universität München, Munich.

Boake, T.M., 2014. Hot climate double façades: Avoiding solar gain. In: Facade Tectonics, University of Waterloo, Canada.

Boake, T.M., Harrison, K., Collins, D., Balbaa, T., Chatham, A., Lee, R. and Andre, B., 2001. The Tectonics of the Double Skin: Green Building or Just More Hi-Tech Hi-Jinx? What are Double Skin Facades and How Do They Work? Case studies, University of Waterloo, Waterloo.

Cetiner, I. and Ozkan, E., 2005. An approach for the evaluation of energy and 
cost efficiency of glass facades. Energy and Buildings, 37, pp.673-684.

Ghasemi, N. and Ghasemi, F., 2017. Double-skin façade technology and its aspects in field of aesthetics, environment and energy consumption optimization. International Journal of Scientific Study, 5, pp.293-307.

Hamza, N. and Underwood, C., 2005. CFD assisted modeling of double skin facades in hot arid areas. In: $9^{\text {th }}$ International Building Performance Simulation Association Conference (IPBSA), Montreal.

Hamza, N., 2008. Double versus single skin facades in hot arid areas. Energy and Buildings, 40, pp.240-248.

Hashemi, N., Fayaz, R. and Sarshar, M., 2010. Thermal behaviour of a ventilated double skin facade in hot arid climate. Energy and Buildings, 42, pp.1823-1832.

Knaack, U., Klein, T., Bilow, M. and Auer, T., 2007. Façades: Principles of Construction. Birkhauser Verlag AG, Berlin.

Kragh, M., 2000. Building Envelopes and Environmental Systems Permasteelisa R\&D and the increasingly required integral design approach. In: Modern Façades for Office Buildings. Delft Technical University, Netherlands.

Lam, J., 2000. Energy analysis of commercial buildings in subtropical climates. Building and Environment, 35, pp.19-26.

Poirazis, H., 2004. Double Skin Façades for Office Buildings, Literature Review, Lund University, Lund.
Radhi, H., Sharples, S. and Fikiry, F., 2013. Will multi-facade sysems reduce cooling energy in fully glazed buildings? A scoping study of UAE buildings. Energy and Buildings, 56, pp.179-188.

Rubel, F. and Kottek, M., 2010. Observed and projected climate shifts 19012100 depicted by world maps of the Köppen-Geiger climate classification. Meteorologische Zeitschrift, 19, pp.135-141.

Streicher, W., Heimrath, R., Hengsberger, H., Mach, T., Waldner, R., Flamant, G., Loncour, X., Guarracino, G., Erhorn, H., Erhorn-Kluttig, H., Santamouris, M., Farou, I., Duarte, R., Blomsterberg, A., Sjöberg, L. and Blomquist, C., 2005. BESTFACADE-Best Practice for Double Skin Facades, Report No. WP1.

Wallner, J. and Pottmann, H., 2011. Geometric computing for freeform architecture. Journal of Mathematics in Industry, 1, p.4.

Yagoub, W., Appleton, S. and Stevens, W., 2010. Case study of double skin façade in hot climates. In: Adapting to Change: New Thinking on Comfort, Network for Comfort and Energy Use in Buildings, London.

Yellamraju, V., 2004. Evaluation and Design of Double-Skin Facades for Office Buildings in Hot Climates, MSc Thesis, Texas A\&M University, College Station.

Zhou, J. and Chen, Y., 2011. A review on applying ventilated double-skin facade to buildings in hot-summer and cold-winter zone in China. Renewable and Sustainable Energy Reviews, 15(3), pp.1468-1475. 